\title{
KREOWANIE WARTOŚCI MARKI TERYTORIALNEJ W KONTEKŚCIE KONCEPCJI WSPÓłTWORZENIA WARTOŚCI
}

\section{Wprowadzenie}

Badania związane $\mathrm{z}$ marką, w tym marką terytorialną, są prowadzone przez przedstawicieli wielu dyscyplin naukowych i odnoszą się do różnych aspektów marki terytorialnej. W niniejszym opracowaniu dokonano wielopłaszczyznowej analizy marki terytorialnej, akcentując zwłaszcza jej wymiar społeczno-kulturowy oraz przedstawiając jej znaczenie w kontekście rozwoju marketingu terytorialnego. Wpisując się w tekst całego opracowania, zamierzeniem autora było podjęcie próby zaprezentowania marki terytorialnej jako określonej wartości rynkowej oraz wskazanie możliwości współtworzenia tej wartości przez najważniejszą grupę odbiorców oferty terytorialnej, tj. przez mieszkańców.

Proces budowania rozpoznawalnej marki staje się w warunkach nasilającej się konkurencji na rynku coraz ważniejszym narzędziem kształtowania przewagi konkurencyjnej. W odniesieniu do marek terytorialnych przewaga ta uwidacznia się m.in. w skuteczniejszym na tle innych jednostek przyciąganiu inwestorów, turystów, studentów czy też przyszłych mieszkańców. Silna marka danego terytorium, pełniąca funkcję marki parasolowej generuje wartość dla różnych grup interesariuszy, w tym zwłaszcza dla mieszkańców. Mając na uwadze dobrobyt swoich mieszkańców jednostki o znanej, silnej marce skuteczniej konkurują o czynniki, dzięki którym mogą zapewnić systematyczny rozwój jednostki, znajdujący odzwierciedlenie w poprawie poziomu jakości życia lokalnej społeczności. Należy jednak podkreślić, że mieszkańcy nie tylko czerpią korzyści z wykreowanej, silnej marki terytorialnej, ale sami współuczestniczą w podnoszeniu jej wartości.

Celem opracowania jest przedstawienie marki terytorialnej jako określonej kategorii wartości, którą można ocenić za pomocą wybranych mierników 
czy rankingów oraz wskazanie możliwości jej wzmacniania zgodnie z założeniami koncepcji współtworzenia wartości opartej na modelu DART.

\title{
Kategoria wartości marki terytorialnej
}

\author{
Wartość marki można określić za L. Żabińskim jako
}

\begin{abstract}
pewną, dodatkową (ponad właściwości funkcjonalne produktu) użyteczność dla nabywcy, za którą jest on gotów zapłacić więcej aniżeli wynikałoby to z właściwości fizycznych produktu". Wartość marki zdaniem cytowanego autora jawi się zatem jako „dodatkowa cecha dodana do produktu, dzięki której produkt zyskuje większą zdolność do zaspokajania potrzeb konsumentów oraz przynosi wymierne korzyści właścicielowi marki [Żabiński 2002: 180].
\end{abstract}

W literaturze przedmiotu podkreśla się, że nie można stawiać znaku równości pomiędzy brandingiem produktów komercyjnych a brandingiem miast i regionów [Glińska 2016: 126]. W odróżnieniu do przedsiębiorstw, jednostka terytorialna nie ma bowiem swojego właściciela, a tym samym nie może stanowić jako całość przedmiotu transakcji (miasta nie można sprzedać). Zdaniem E. Glińskiej trudno jest również wyraźnie zidentyfikować „producentów” oferty terytorialnej, gdyż reprezentują oni szerokie grono interesariuszy, często prezentujących odmienne interesy [Glińska 2016: 115].

Licznie autorzy zajmujący się problematyką marki podkreślają, że powstaje ona wówczas, gdy zaistnieje w umysłach konsumentów i spowoduje ich świadomy wybór [Kall 2006: 13-14]. Źródłem siły marki, tworzącej jej wartość, są efekty komunikacyjne (świadomość, wizerunek) i behawioralne (zachowania składające się na lojalność wobec marki), [Kall, Kłeczek, Sagan 2006: 89].

Markę terytorium według V. Virgo i L.de Chernatony’a należy charakteryzować poprzez zestaw funkcjonalnych i emocjonalnych wartości, które przyczyniają się do tego, że jest ona wyjątkowa i zawiera obietnicę zaspokojenia potrzeb określonych grup klientów w oryginalny, różny od konkurencji sposób [Vigro, Chernatony 2006: 379-392].

Korzyści wynikające w wykreowania silnej marki odnoszą się do wielu grup interesariuszy, zarówno zewnętrznych jak i wewnętrznych. Silna marka terytorium utrwala przede wszystkim jego rozpoznawalność i wyróżnia go na tle innych jednostek terytorialnych, co wzmacnia siłę przyciągania interesariuszy, którzy inwestują swoje środki w danym terytorium. Ważne jest by wszystkie grupy podmiotów zaangażowanych w proces tworzenia marki konsekwentnie dążyły do utrwalenia pozytywnych, unikalnych, spójnych 
wewnętrznie skojarzeń związanych $\mathrm{z}$ daną marką. W praktyce posiadanie wykreowanej marki przez jednostkę terytorialną oznacza, że spośród wielu podobnych jednostek o porównywalnych cechach i uwarunkowaniach rozwoju, określone terytorium uzyskuje lepszą zdolność konkurowania i może osiągnąć wyższą cenę za sprzedaż określonych elementów subproduktów współtworzących strukturę megaproduktu terytorialnego (np. w Zakopanem czy w Sopocie za podobne warunki pobytu w hotelu należy zapłacić więcej aniżeli w mniej znanej destynacji turystycznej).

Należy podkreślić, że silna marka ułatwia nie tylko podejmowanie decyzji lokalizacyjnych wśród zewnętrznych adresatów oferty terytorialnej, ale także kształtuje postawy i zachowania lokalnej społeczności. Ujawnia się to m.in. we wzmacnianiu stopienia identyfikacji mieszkańców ze swoim miejscem zamieszkania, kształtowaniu poczucia wewnętrznej dumy z przynależności do danego miasta/regionu czy też motywuje do współuczestniczenia w kreowaniu wartości marki terytorium.

\section{Ocena wartości marki terytorialnej - wybrane mierniki}

W odniesieniu do marki miejsca, efekty stanowiące wynik budowania marki określonej jednostki terytorialnej można za A. Lucarelli zakwalifikować do trzech zasadniczych grup:

- związane $\mathrm{z}$ wizerunkiem i tożsamością (obejmujące m.in. zmianę percepcji jednostki wśród turystów czy mieszkańców),

- społeczno-polityczne (obejmujące m.in. wpływ interesariuszy na proces brandingu, angażowanie mieszkańców),

- ekonomiczne (obejmujące m.in. wydatki turystów, wpływy do budżetu miasta $\mathrm{z}$ podatków, ceny nieruchomości czy też miejsca pracy), [Lucarelli 2012: 231-252].

Proces kreowania marki można uznać za skuteczny, gdy osobom odpowiedzialnym za jej kształtowanie uda się pozytywnie zmienić sposób postrzegania danej jednostki, tym samym zwiększyć jej kapitał. W interesujący sposób skuteczność procesu kreowania marki terytorium określa S. Anholt. Cytowany autor uznaje, że silna marka terytorium powinna prezentować cechy magnesu, to znaczy przyciągać to co wartościowe (np. inwestorów, turystów, uwagę, szacunek), nadawać właściwości magnetyczne innym obiektom (np. produktom pochodzącym z danej jednostki), a także czynić porządek $\mathrm{z}$ chaosu (atrakcyjna oferta jednostki może przekonać do siebie zróżnicowane grupy interesariuszy, nawet jeśli ich cele nie są współbieżne), [por. Glińska 2016: 130]. 
David Aaker wskazuje pięć metod obliczania wartości marki:

- metodę cen premiowych (np. elementy marki danego miasta umożliwiają zastosowanie cen wyższych od cen konkurencji i w ten sposób osiągnięcie większego zysku),

- metodę wyceny według preferencji konsumentów - (np. w turystyce weryfikowany jest wpływ marki określonej destynacji turystycznej na decyzje wyboru miejsca wypoczynku, intencji wyjazdu, preferencji),

- metodę wyceny wg kosztów zastąpienia - (np. szacuje się koszty wykreowania marki terytorium do porównywalnej jednostki o neutralnym wizerunku),

- metodę opartą na ruchach cen giełdowych,

- metodę opartą na zdolności do zarabiania - (np. oszacowanie przychodów przez używanie marki znanego terytorium przy prowadzeniu określonej działalności w przyszłości), [Aaker 1991: 22-27].

Współcześnie istnieje wiele różnego typu wskaźników, rankingów czy też klasyfikacji krajów, regionów, miast, miejscowości turystycznych, które oceniają marki terytorialne. Większość z nich odnosi się do dużych terytoriów, uwzględniających wybrane obszary aktywności. Szczegółowej analizy metod pomiaru skuteczności budowania marek miast dokonały m.in. A. Augustyn, M. Hereźniak, M. Florek, podkreślając, że w pomiarze marki terytorialnej wskazane jest "równoległe” zastosowanie kilku wybranych metod pomiarowych, uwzględniających materialne i niematerialne (wizerunkowe, emocjonalne) rezultaty [Augustyn, Hereźniak, Florek 2017: 43].

Wartość marki terytorialnej można oceniać za pomocą pomiaru wybranych cech marki (np. symbolika, rozpoznawalność, sugestywność, łatwość zapamiętania) bądź też cyklicznych rankingów, stanowiących miernik potencjału wizerunkowego określonych jednostek terytorialnych. Pomocnym narzędziem w tym zakresie mogą być systematycznie obliczane indeksy miast, odzwierciedlające ich ogólną atrakcyjność bądź też atrakcyjność w wybranych obszarach aktywności, np. jakości życia - Human Development Index (HDI), biznesu i inwestycji zagranicznych - Trust Index. Jak wskazują A. Augustyn, M. Hereźniak, M. Florek, w przypadku dużych miast najczęściej przytaczanymi wskaźnikami są: wskaźniki globalne (np. Global City Index Report, Gobal Power City Index), z zakresu handlu i finansów (Global and World Cities Project, Global Financial Centres) oraz z zakresu kosztów życia i jakości życia (Mercer Cost of Living Report, Mercer Quality of Living Report), [Augustyn, Hereźniak, Florek 2017: 39]. 
Wśród stosowanych mierników szczególnie dużą popularnością cieszy się Indeks Anholta, stanowiący miernik potencjału wizerunkowego największych miast świata. Badanie „Anholt-GfK Roper City Brands Index” przeprowadzane jest co 2 lata i mierzy wizerunek 50 miast. Fundament analizy stanowi kwestionariusz z przeszło 50 pytaniami. Rezultaty ustala się na podstawie ponad 5 tysięcy wywiadów realizowanych w kilkunastu krajach świata. Kluczowy indeks stanowiący orientacyjny miernik marki miasta zawiera sześć składowych ${ }^{1}$ :

1. Powszechne postrzeganie miasta (wspólny status oraz pozycja miasta).

2. Miejsce (zaopiniowanie jego położenia).

3. Ogólne warunki życia (m.in. opłaty zakwaterowania, a także powszedniość usług publicznych).

4. Ludzie.

5. Rytm miasta (tj. kultura, atrakcyjne działania, w jakich można wziąć udział).

6. Potencjał miasta (zdolności zarobkowe oraz edukacyjne).

Najwyżej oceniane w 2015 roku miasta to Paryż, Londyn, Nowy Jork, Sydney, Los Angeles. Warto zaznaczyć, że Warszawa uplasowała się w pierwszej pięćdziesiątce ${ }^{2}$.

Należy podkreślić, że najpopularniejszy indeks miast obejmuje w swym pomiarze przede wszystkim cechy i atrybuty miejsca znajdujące się na samym dole zaproponowanej przez B. Beakera piramidy korzyści marki miejsca [Baker 2007: 111]. Według cytowanego autora dół piramidy stanowią podstawowe cechy i atrybuty marki miejsca (np. walory naturalne, warunki klimatyczne, wydarzenia kulturalne, architektura). Korzyści racjonalne (funkcjonalne) stanowią drugi poziom piramidy obejmujący kulturę, dostęp do usług, bezpieczeństwo czy też koszty. Górną część piramidy stanowią korzyści emocjonalne, wpływające na emocje i uczucia osób, „doświadczających” kontaktu z miejscem. W wierzchołku piramidy znajdują się wartości i korzyści autoekspresywne, odzwierciedlające głębokie emocjonalne potrzeby i wartości zaspokajane przez miejsce, wpływające na autowizerunek osoby [Baker 2007: 111]. Im wyżej w piramidzie usytuowane są elementy składowe, tym trudniej jest dokonać obiektywnej oceny ich atrakcyjności, które z kolei są niezmiernie ważne dla „klientów” określonej

1 Szerzej: https://infowire.pl/generic/release/341340/spadaja-wskazniki-reputacji-krajow-z-pierwszejdziesiatkiswiatowego-rankingu-anholt-gfk, [29.04.2018].

2 Szerzej http://www.gfk.com/tr/icgoerueler/press-release/new-anholt-gfk-city-brands-ranking-places-three-us-cities-in-the-top-10/, [02.10.2017]. 
marki terytorium. Są one zarazem najtrudniejsze do skopiowania i do dostarczania przez markę. Z kolei cechy znajdujące się na dole piramidy są najłatwiejsze do zaoferowania przez dane terytorium, a zarazem łatwe do skopiowania, nie wnoszą one jednak unikalności, która ma zasadnicze znaczenie przy kreowaniu wartości marki, tzw. USP.

Poza indeksem miast Anholta, można wyróżnić wiele innych mierników, prezentujących atrakcyjność konkretnych terytoriów, z których większość zawężana jest tylko do wybranych cech świadczących o atrakcyjności danej marki, np. Ranking bezpieczeństwa w 50 miastach świata przygotowany przez brytyjski ośrodek analityczny Economist Intelligence Unit. Przy uwzględnieniu 19 mierników ilościowych i 25 jakościowych, według Raportu w 2016 roku najbezpieczniejszymi miastami na świcie były: Tokio, Singapur, Osaka, Sztokholm, Amsterdam i Sydney. Wśród miast europejskich na czele rankingu są miasta Norwegii (Bergen, Trondheim), Niemiec (Monachium) i Szwajcarii (Brno, Zurych. Należy zaznaczyć, że wśród 30 najbezpieczniejszych, dużych miast Europy znalazły się Warszawa i Gdańsk.

Z punktu widzenia pomiaru wartości marki terytorium warto wskazać również na badanie Saffron's European City Brand Barometer, które zakłada ocenę miast w dwóch wymiarach: siła zasobów miasta (city asset strength) oraz siła marki miasta (city brand strength). W obrębie kategorii Siła marki miasta uwzględniana jest $\mathrm{m}$.in. siła pozytywnych skojarzeń $\mathrm{z}$ miastem, test pocztówkowy, wartość konwersacyjna, obecność miasta w mediach [Dudek-Mańkowska, Balkiewicz-Żerek 2015: 18-19].

Kolejnym miernikiem marki miasta jest BrandAsset Valuator (BAV). W teorii BAV do badania siły marki terytorialnej wykorzystuje się unikalność i atrakcyjność, w obrębie której wyróżnia się atrakcyjność poznawczą oraz atrakcyjność emocjonalną. Badanie zakłada, że atrakcyjność miasta jest wektorem określającym siłę przyciągania trzech grup interesariuszy: turystów, mieszkańców i inwestorów [Dudek-Mańkowska, Balkiewicz-Żerek 2015: 18-19].

W Polsce badania nad markami terytorialnymi znajdują się we wstępnej fazie rozwoju. Jednym z pierwszych było badanie przeprowadzone przez Agencję Young@Rubicam Magnetyzm polskich miast (MMP) ${ }^{3}$, którego metodologia była oparta na założeniach metody BrandAsset Valuator. Badanie to miało na celu analizę wizerunkową i ocenę kondycji wybranych marek-miejsc, a także porównywanie ich pomiędzy sobą na podstawie

3 Szerzej: Miejsce jako marka - „Magnetyzm polskich miast”, http://www.wspolnota.org.pl/ aktualnosci/aktualnosc/miejsce-jako-marka-magnetyzm-polskich-miast, [25.08.2017]. 
wyodrębnionych, jednakowych dla wszystkich terytoriów cech. W podobny sposób prowadzonych jest również wiele rankingów specjalistycznych, jak np. Ranking miast uczących się czy też Ranking polskich bezpiecznych i otwartych miast ${ }^{4}$.

Dzięki prowadzonym badaniom potencjału wizerunkowego terytoriów oraz siły marki można określić sposób postrzegania danej jednostki, który jak wynika $\mathrm{z}$ prowadzonych badań, w wyjątkowych przypadkach na skutek negatywnych stereotypów sygnalizuje problemy związane negatywnym postrzeganiem miasta (przykładem może tu być miasto Pruszków, które kojarzone jest z siedzibą mafii, lub Katowice, które utożsamiane są z brudem czy pokopalnianymi ruderami). Taki sposób postrzegania danej jednostki wymaga wielokierunkowych działań, mających na celu zneutralizowanie negatywnych skojarzeń i konsekwentne budowanie marki terytorium w oparciu o unikalną propozycję sprzedaży (USP) danej jednostki.

\section{Koncepcja współtworzenia wartości a możliwości współudziału mieszkańców w kreowaniu marki terytorium}

U podstaw nowego podejścia do tworzenia wartości leży zaproponowana przez S. L. Vargo i R. F. Lusch’a koncepcja „Logiki dominacji usług” zakładająca, że podstawę wymiany stanowią usługi, rozumiane jako zastosowanie wyspecjalizowanych kompetencji, np. wiedzy i umiejętności poprzez czyny, procesy i produkcję w celu osiągnięcia korzyści [Vargo, Lusch 2004: 2]. Według takiego podejścia wartość powstaje w wyniku procesu współtworzenia, w którym priorytetową rolę odgrywa konsument. W odniesieniu do wartości marki terytorium są to interesariusze jednostki. W literaturze przedmiotu mocno podkreśla się konieczność ich angażowania do wszystkich etapów brandingu miejsca. Dotyczy to zwłaszcza mieszkańców, których współuczestniczenie w tym procesie prowadzi do wzrostu poczucia własności marki, a w konsekwencji większego poczucia odpowiedzialności za jej rozwój, zarządzanie i zewnętrzną reputację [Brown, Kavaratzis, Zenker 2013: 31-38]. Niestety, wciąż jest niewiele badań, które opisywałyby udział mieszkańców w procesie kreowania marki miejsca, na co wskazują m.in. M. Stuart i A. Insch. Większość publikacji, jak podkreślają cytowani autorzy, skupia się głównie na klasyfikowaniu mieszkańców jako

4 Szerzej na stronie Polskiej Fundacji im Roberta Schumana, http://europolis.schuman.pl/raport, [21.04.2018]. 
klientów miejsca, pomijając kwestie związane z ich aktywnym udziałem w kreowaniu wartości marki terytorium [por. Glińska 2015: 195]. Z punktu widzenia zaangażowania mieszkańców w proces kreowania marki i wizerunku jednostki ważną rolę pełni budowanie więzi między jednostką a mieszkańcami przez działania PR, które powinny zmierzać do nawiązania oraz utrzymania więzi z mieszkańcami, budowania wzajemnego szacunku i odpowiedzialności czy też zapobiegania nieporozumieniom i konfliktom [Glińska, Florek, Kowalewska 2009: 132].

W koncepcji współtworzenia wartości zakłada się występowanie symetrycznego dostępu do informacji, kultywowanie dialogu, budowanie sieci tworzącej wartość, uczenie się przez wymianę oraz przyjęcie perspektywy relacyjnej. Wymusza to ze strony jednostek terytorialnych konieczność stworzenia systemu komunikacji dwustronnej oraz przyjęcia perspektywy uwzględniającej interakcyjny charakter komunikacji oraz możliwość zmiany ról komunikacyjnych. Odbiorcy przekazu dzięki zachodzącym interakcjom coraz częściej kreatywnie reagują na wysyłane komunikaty jak też sami je redagują, współtworząc tym samym wartość marki określonego terytorium $\mathrm{W}$ ostatnich latach nasila się ponadto komunikacja $\mathrm{w}$ hipermedialnym środowisku komputerowym, umożliwiającym zindywidualizowany, dwukierunkowy typ relacji między uczestnikami kanału, będący odzwierciedleniem sieciowego paradygmatu rozwoju.

Coimbatore K. Prahalad i Venkat Ramaswamy określają, że interakcje tworzone pomiędzy przedsiębiorstwem a klientem w procesie współtworzenia wymagają respektowania czterech zasadniczych założeń ( tzw. Model DART: Dialog (Dialogue), Dostęp (Access), Transparentność (Transparancy), Ocena ryzyka (Risk Assessment). Wymienione elementy modelu DART powinny być również respektowane w procesie kreowania marki terytorialnej, przez różne możliwości włączenia mieszkańców w proces współudziału w kreowaniu jej wartości [Prahalad, Ramaswamy 2004: 23-31)].

Dialog - w odniesieniu do jednostki terytorialnej można wskazać wiele przykładów wymiany czy dzielenia się wiedzą, czego odzwierciedleniem mogą być m.in. konsultacje społeczne, bezpośrednie spotkania władz lokalnych z mieszkańcami czy prowadzenie dialogu z lokalną społecznością poprzez fora internetowe, portale społecznościowe.

Dostęp - odzwierciedleniem wyodrębnionej cechy w kreowaniu wartości marki terytorium może być współudział w ich projektowaniu elementów składowych marki, wstępnym testowaniu czy też modyfikowaniu.

Transparentność - przejrzystość przekazu komunikującego walory marki poprzez tradycyjne (gazetki lokalne, foldery informacyjne), jak też 
nowoczesne (Internet) kanały przekazu, umożliwiające bieżące śledzenie wydarzeń, zadawanie pytań, czy też dzielenie się swoimi pomysłami i spostrzeżeniami.

Ocena ryzyka - zaangażowanie mieszkańców w rozwój swojej jednostki oraz kreowanie jej marki przez propozycje alternatywnych rozwiązań, przejmowanie przez nich części odpowiedzialności za zagrożenia związane z niewłaściwymi decyzjami czy działaniami lokalnych władz [Kuźniar, Kawa 2015: 279-288].

Respektowanie wyodrębnionych zasad kreuje nową jakość relacji jednostki terytorialnej z mieszkańcami, powodując obustronne korzyści, np.:

- połączenie dostępu oraz transparentności stanowi podstawę dialogu między równoprawnymi partnerami, umożliwiając podejmowanie lepszych decyzji związanych $\mathrm{z}$ rozwojem marki,

- dostęp i dialog umożliwiają rozwijanie i utrzymywanie tematycznych społeczności, zgrupowanych wokół danego miejsca i jego marki,

- dialog i ocena ryzyka - sprzyjają prowadzeniu debaty i wspólnemu opracowaniu określonych rozwiązań w zakresie kreowania marki,

- transparentość i ocena ryzyka umożliwiają wspólne budowanie zaufania [Dziewanowska 2003: 46].

Odnosząc się do najważniejszych założeń koncepcji współtworzenia można opierając się na załażeniach C. K. Prahalada, V. Ramaswamy wskazać kilka niezbędnych warunków jej realizacji w procesie kreowania marki terytorium. Zdaniem autorki powinny one obejmować przede wszystkim [Prahalad, Ramaswamy 2004:.8]:

- zerwanie $\mathrm{z}$ tradycyjnym oddzieleniem procesu tworzenia wartości marki z procesem jej doświadczania,

- wspólne działania podmiotów odpowiedzialnych za kreowanie marki terytorium, w tym zwłaszcza władz lokalnych z mieszkańcami, zmierzające do tworzenia wartości, która poza korzyściami funkcjonalnymi coraz mocniej eksponuje korzyści emocjonalne, społeczne i ekologiczne,

- wspólne definiowanie problemów związanych z procesem kreowania/wzmacniania marki terytorium, głównie poprzez kontakty bezpośrednie, portale społecznościowe oraz wspólne poszukiwanie sposobów ich rozwiązywania

- otwartość władz lokalnych na wszelkie rozwiązania innowacyjne, zwłaszcza w zakresie komunikacji, co umożliwia aktywny dialog oraz pozwala współtworzyć i przeżywać tworzenie wartości marki terytorium, oferującej jej „klientom” zbiór określonych korzyści. 
Należy pamiętać, że o unikalności i wartości marki terytorium decydują przede wszystkim korzyści emocjonalne, wpływające na emocje i uczucia osób, „doświadczających” kontaktu z miejscem oraz wartości i korzyści autoekspresywne, odzwierciedlające głębokie emocjonalne potrzeby i wartości zaspokajane przez ofertę określonego terytorium.

Warto podkreślić, że zaangażowanie mieszkańców w proces współtworzenia marki i wizerunku jednostki jest uzależnione od ich świadomości, aktywności czy też posiadanych kompetencji społecznych. W literaturze przedmiotu wyodrębnia się różne typologie mieszkańców, której punktem odniesienia jest podział T. Domańskiego, wyróżniający tzw. grupy mało mobilne, stanowiące większość mieszkańców danej społeczności oraz grupy o wysokim potencjale mobilności, które często pełnią rolę liderów opinii publicznej [Domański 1997: 22-23]. Z punktu widzenia kreowanej marki terytorium szczególnie ważną rolę należy przypisać drugiej grupie, do której zalicza się m.in. osoby pełniące ważne funkcje społeczne. Istotną rolę do odegrania mają znane, wpływowe osoby pochodzące z określonej miejscowości (np. artyści, sportowcy, naukowcy), które stają się niejako „ambasadorami” danego miejsca, zwiększając jego atrakcyjność przez wywoływanie pozytywnych skojarzeń i rozpowszechnianie informacji o swojej rodzinnej miejscowości, co wzmacnia proces kreowania jej marki. Mieszkańcy stają się zatem swoistymi nośnikami komunikatów promocyjnych i swoją postawą wzmacniają profesjonalne działania wizerunkowe a w konsekwencji wzmacniają wartość marki terytorialnej.

\section{Wnioski}

Marka terytorium jest kategorią złożoną i wielowymiarową, co było wielokrotnie akcentowane w całościowej treści opracowania. $O$ jej postrzeganiu przez interesariuszy oraz pozycji na tle marek konkurencyjnych świadczy wiele elementów składowych, charakteryzowanych przez autorów publikacji, które współtworzą złożoną strukturę megaproduktu terytorialnego.

W celu oceny pozycji marki terytorium jednostki badawczo - doradcze wypracowały wiele mierników, służących określeniu rankingów miast i regionów, nie tylko w skali globalnej czy europejskiej, ale także krajowej i regionalnej. Mierniki te bazują zarówno na percepcji różnorodnych zasobów miejsca i oferowanych przez nie korzyści, jak również postrzeganiu elementów emocjonalnych, charakteryzujących daną jednostkę i przesądzających w dużej mierze o jej unikalności O ile do badania podstawowych korzyści oferowanych przez markę, tj. tzw. korzyści racjonalnych (funkcjonalnych) 
wykorzystuje się gównie badania ilościowe, to weryfikacja korzyści emocjonalnych, wymaga zastosowania badań jakościowych, pozwalających dotrzeć do motywów działania.

$\mathrm{W}$ niniejszym opracowaniu $\mathrm{w}$ wielu rozdziałach wielokrotnie podkreślano, że marka powstaje wówczas, gdy zaistnieje w umysłach odbiorów oferty terytorialnej i spowoduje ich świadomy wybór jako miejsca do zamieszkania, studiowania, inwestowania czy też zwiedzania. Dzięki temu zwiększa się wartość marki terytorium, a jednostka wzmacnia swą pozycję konkurencyjną na tle innych jednostek. Proces ten nie byłby jednak możliwy, bez zaangażowania wielu grup podmiotów odpowiedzialnych za rozwój jednostki, wśród których szczególnie ważną rolę mają do odegrania mieszkańcy. Często roli tej na poziomie jednostek terytorialnych niestety się nie docenia. Tymczasem zgodnie z koncepcją współtworzenia wartości nie wystarcza już traktowanie mieszkańców jako jednej z grup docelowych jednostki terytorialnej, nawet jeśli byłaby to grupa traktowana priorytetowo. Konieczne staje się zaangażowanie lokalnej społeczności, w tym zwłaszcza tzw. liderów opinii zarówno w kreowanie procesu rozwoju marki (dzielenie się pomysłami, współdecydowanie), jak też implementację. Kluczowe znaczenie w tym względzie będzie miał dialog, który nie może się jednak ograniczać do wymiany informacji czy dzielenia się wiedzą, ale musi oznaczać nową jakość relacji, odzwierciedlającą zgodnie z założeniami modelu DART interaktywność, głębokie zaangażowanie, zdolność do słuchania, czy też empatyczne zrozumienie doznań interesariuszy.

\section{Bibliografia}

Aaker D. (1991), Managing brand equity, New York.

Augustyn A., Hereźniak M., Florek M. (2017), W poszukiwaniu wiarygodnych metod pomiaru skuteczności budowania marek miast, „Zeszyty Naukowe Szkoły Głównej Gospodarstwa Wiejskiego w Warszawie, Polityki Europejskie, Finanse i Marketing”, nr 17 (66).

Baker B. (2007), Destination branding for small cites: The essentials for successful place branding, Portland.

Brown E., Kavaratzis M., Zenker S. (2013), My city - my brand: The different roles of residents in place branding, "Journal of Place Management and Development", nr 6(1), s. 31-38.

Domański T. (1997), Marketing terytorialny - wybrane aspekty praktyczne, [w:] T. Domański (red.), Marketing terytorialny. Strategiczne wyzwania dla miast i regionów, Łódź.

Dudek-Mańkowska S., Balkiewicz-Żerek A. (2016), Siła marki miejsca, „Marketing i Rynek", nr 6, s. 18-19. 
Dziewanowska K. (2013), Wykorzystanie koncepcji wspóltworzenia w nowym podejściu marketingowym, „Handel Wewnętrzny”, nr 3, s. 46.

Glińska E, Florek M, Kowalewska A. (2009), Wizerunek miasta, od koncepcji do wdrożenia, Warszawa.

Glińska E. (2016), Budowanie marki miasta. Koncepcje, warunki, modele, Warszawa.

Kall J. (2006), Jak zbudować silnq markę od podstaw, Gliwice.

Kall J., Kłeczek R., Sagan A. (2006), Zarzadzanie marką, Warszawa.

Keller K.L. (2016), Strategiczne zarządzanie marką, Warszawa.

Kuźniar W., Kawa M. (2015), Relacje jednostek samorzadu terytorialnego z mieszkańcami w kontekście koncepcji wspóltworzenia wartości, [w:] A. Samlec (red.), Marketing przyszłości. Trendy. Strategie. Instrumenty. Komunikacja marketingowa w sferze publicznej i społecznej, „Zeszyty Naukowe Uniwersytetu Szczecińskiego nr 87. Problemy Zarządzana, Finansów i Marketingu”, nr 40, s. 279-288.

Lucarelli A. (2012), Unraveling the complexity of „city brand equity”: a three-dimensional framework, "Journal of Place Management and Development", nr 5(3), s. 231-252.

Prahalad C. K., Ramaswamy V. (2004), The future of competition. Co-Creating Unique Value with Costumers, Boston MA.

Prahalad C. K, Ramaswamy V. (2004), Co-creation experiences: the next practice in Value creation, "Journal of Interactive Marketing", nr 18(3), s. 8.

Vargo S. L., Lusch R. F. (2004), Evollving to a New dominant logic for marketing, "Journal of Marketing", nr 68, s. 2.

Vigro B, Chernatony L. (2006), Delphic brand visioning to align stakeholder buy-in to the city of Brimingham brand, "Journal of Brand Management", nr 13(6), s. 379-392.

Żabiński L. (red.) (2002), Marketing: koncepcje, badania, zarządzanie, Katowice.

\section{SUMMARY}

\section{Creating the territorial brand value in the conext of value co-creation concept}

The purpose of the chapter is to present the territorial brand as a specific market value and to indicate the possibility of co-creating this value by the most important group of recipients of the territorial offer, that is, by the residents. Selected methods of territorial brand measurement were presented, taking into account its various features and the most important indices defining the value of territorial brands were indicated. Special attention was paid to the possibilities of co-creating territorial value by the local community, and especially the so-called opinion leaders. It was emphasised that in the process of co-creating the brand's value by the residents, a dialogue with stakeholders is of key importance, meaning interactivity, deep involvement, ability to listen, or empathic understanding of stakeholder's experience by local government representatives. The residents in the process of creating the brand's value, thanks to their knowledge and commitment, become specific carriers of promotional messages and their attitude strengthens professional image-building activities, which in turn strengthens the value of the territorial brand.

KEYWORDs: territorial brand, measures, value co-creation, dialogue 